\title{
An updated cause specific mortality study of petroleum refinery workers
}

\author{
T G Dagg, K P Satin, W J Bailey, O Wong, L L Harmon, R E Swencicki
}

\begin{abstract}
An update of a cohort study of 14074 employees at the Richmond and El Segundo refineries of Chevron USA in California was conducted to further examine mortality patterns. The update added six years of follow up $(1981-6)$ and 941 deaths. As in the previous study, mortality from all causes (standard mortality ratio $(S M R)=73$ ) was significantly lower among men compared with the general United States population. Significant deficits were also found for all cancers combined $(S M R=81)$, several site specific cancers, and most non-malignant causes of death. Mortality from suicide was increased relative to the United States as a whole. Based on a comparison with California rates, however, men had fewer deaths from suicide than expected. Standard mortality ratios were raised for several other causes of death, but only leukaemia and lymphoreticulosarcoma exhibited a pattern suggestive of an occupational relation. The increase appeared to be confined to those hired before 1949, and in the case of lymphoreticulosarcoma, to Richmond workers.
\end{abstract}

In 1983, a mortality study of current and former Chevron employees at the Richmond and El Segundo refineries was completed. ${ }^{1}$ The observation period of the original study extended from 1 January 1950 to 31 December 1980, and comprised all employees who worked at least one year at either refinery (a day of which had to fall within the

Chevron Corporation Medical Staff, 225 Bush Street, San Francisco, CA, 94104, USA

T G Dagg, K P Satin, W J Bailey, L L Harmon, R E Swencicki

Applied Health Sciences, 181 Second Avenue, Suite 628, San Mateo, CA, 94401 , USA

O Wong observation period). For both refineries, mortality from all causes was significantly below that expected based on rates for the United States. Significantly lower rates were also found for several cause specific categories including digestive cancer, lung cancer, heart disease, non-malignant respiratory disease, and accidents. Non-significant increases were found for some disease categories; however, only lymphopoietic cancer exhibited a pattern of increased risk suggestive of a possible occupational relation. Whereas this excess appeared to be confined to workers hired at the Richmond refinery before 1949, further follow up was recommended to provide longer latency among employees hired after that date.

The follow up of this cohort has been extended to 31 December 1986. An analysis of the updated information was carried out to further evaluate deaths due to lymphopoietic cancer, and to look for any new mortality patterns for other causes of death.

\section{Materials and methods}

The original study consisted of 14179 workers at the Richmond and El Segundo refineries, all of whom were employed in either operating and maintenance, clerical, technical, supervisory, or administrative jobs. A comprehensive description of the data collection and cohort verification procedures can be found in a previous publication. ${ }^{1}$ During the update, 105 duplicate records were discovered and excluded. Of the remaining $14074,95 \%$ were men.

Complete work histories were not compiled in the original study. Instead, only first and last jobs (work location, job title, and corresponding dates) were coded to permit an analysis by work location or job category. Whereas these subcohort analyses in the previous study did not identify any major differences in mortality patterns, we attempted to update information on last jobs to further assess potential differences across work locations. Unfortunately, this information was not consistently stored in the available computer files (for example, personnel system, safety and health information system), precluding its use in the current update. Year end personnel tapes 
Table 1 Number of cohort members by sex, refinery location, and vital status (as of 31 December 1986)

\begin{tabular}{|c|c|c|c|c|}
\hline & \multicolumn{3}{|c|}{ Vital status (No (\%)) } & \multirow[b]{2}{*}{ Total } \\
\hline & Alive & Dead $^{\star}$ & Unknown & \\
\hline \multicolumn{5}{|l|}{ Richmond: } \\
\hline Men & $6065(71 \cdot 2)$ & $2038(23.9)$ & $420(4.9)$ & 8523 \\
\hline \multicolumn{2}{|l|}{ El Segundo: } & $38(10.8)$ & & 353 \\
\hline Men & $3460(72 \cdot 5)$ & $1121(23 \cdot 5)$ & $192(4 \cdot 0)$ & 4773 \\
\hline Women & $269(83.0)$ & $24(7 \cdot 4)$ & $31(9 \cdot 6)$ & 324 \\
\hline Total $\dagger$ & $10174(72 \cdot 3)$ & $3228(22.9)$ & $672(4 \cdot 8)$ & 14074 \\
\hline
\end{tabular}

*Copies of death certificates were obtained for $3184(98.6 \%)$ of the descendents.

†The total includes 101 male cohort members who worked at both the Richmond and El Segundo refineries. These workers were excluded from the individual refinery analyses, and therefore are not included in the individual refinery counts.

were used, however, to classify study participants as either active, retired, or terminated from the Richmond or El Segundo refinery as of 31 December 1986. Also, termination dates were recorded for employees who were no longer active at either refinery.

Several sources were utilised to update the vital status of the cohort to 31 December 1986. These included company records, the computerised files of the National Death Index, the earnings and benefits file of the Social Security Administration, the California Death Index microfiche, and Equifax (an information services company that provides cohort member tracing). Death certificates were coded by a trained nosologist according to the eighth revision of the International Classification of Diseases. ${ }^{2}$ To assess intercoder agreement between the study's original nosologist and the coder for the new deaths, a $20 \%$ random sample of new death certificates was recoded by the original nosologist. An intercoder error rate of $1.1 \%$ was found for underlying cause of death, representing a high level of precision. Persons with a known date of death, but for whom a death certificate could not be located, were included in the analysis of total mortality but not in cause specific analyses.

Mortality was analysed using the occupational cohort mortality analysis program (OCMAP) developed by Marsh and Preninger. ${ }^{3}$ This employs a modified life table approach to calculate the standardised mortality ratio (SMR). For most analyses, expected deaths were based on cause specific United States death rates adjusted for age, race, sex, and calendar period. A further analysis of death rates from four causes of death (suicide, malignant melanoma, laryngeal cancer, and Hodgkin's disease) was based on a comparison with California rates, as these rates are substantially different from the corresponding national rates. For all SMRs, 95\% confidence intervals (95\% CIs) were calculated under the assumption that the observed number of deaths followed the Poisson probability distribution. ${ }^{4}$

Cancer mortality at each refinery was also analysed by duration of employment $(<5,5-14,15-29$, and $\geqslant 30$ years) and by interval since hire $(<10,10-19$, $20-29$, and $\geqslant 30$ years). Duration of employment was used in this study as a surrogate for duration of exposure in the workplace. Interval since hire, on the other hand, was used as a surrogate for latency, and was defined as the number of years between initial hire and death or end of follow up (31 December 1986), whichever occurred first.

\section{Results}

As of 31 December 1986, $10174(72 \cdot 3 \%)$ of the

Table 2 Characteristics of male cohort members (as of 31 December 1986) by refinery location

\begin{tabular}{|c|c|c|c|}
\hline \multirow[b]{2}{*}{ Variable } & \multicolumn{2}{|l|}{ Refinery } & \multirow[b]{2}{*}{ Total* } \\
\hline & Richmond & El Segundo & \\
\hline $\begin{array}{l}\text { No in study } \\
\text { Total person-years } \\
\text { Year of hire } \\
\text { Age at hire (y) } \\
\text { Duration of employment }(y) \\
\text { Duration of follow up }(y) \\
\text { Interval since hire }(y) \dagger \\
\text { Age at death }(y)\end{array}$ & $\begin{aligned} & 8523 \\
& 205397 \\
& 1954(1905-79) \\
& 27 \cdot 0(12 \cdot 0-62 \cdot 0) \\
& 16 \cdot 2(0 \cdot 6-51 \cdot 7) \\
& 24 \cdot 1(0 \cdot 0-37 \cdot 0) \\
& 28 \cdot 9(1 \cdot 0-75 \cdot 1) \\
& 65 \cdot 4(20 \cdot 1-97 \cdot 6)\end{aligned}$ & $\begin{aligned} & 4773 \\
& 110594 \\
& 1955(1907-79) \\
& 27 \cdot 9(11 \cdot 8-72 \cdot 8) \\
& 15 \cdot 2(1 \cdot 0-49 \cdot 0) \\
& 23 \cdot 2(0 \cdot 0-37 \cdot 0) \\
& 27 \cdot 7(1 \cdot 0-73 \cdot 0) \\
& 65 \cdot 2(20 \cdot 8-97 \cdot 2)\end{aligned}$ & $\begin{array}{rc}13397 & \\
318837 & \\
1954 & (1905-79) \\
27 \cdot 3 & (11 \cdot 8-72 \cdot 8) \\
15 \cdot 9 & (1 \cdot 0-51 \cdot 7) \\
23.8 & (0 \cdot 0-37 \cdot 0) \\
28.5 & (1 \cdot 0-75 \cdot 1) \\
65 \cdot 3(20 \cdot 1-97 \cdot 6)\end{array}$ \\
\hline
\end{tabular}


cohort members at both refineries were known to be alive, $3228(22.9 \%)$ were deceased, and $672(4.8 \%)$ were of unknown vital status (table 1). Copies of death certificates were obtained for $3184(98.6 \%)$ of the decedents. Thirteen per cent of the cohort were actively employed at the end of follow up.

Male cohort members $(n=13397)$ contributed a total of 318837 years of observation over the entire 37 year study period, with a further 64000 years being added during this update (table 2 ). The average duration of follow up (after satisfying all entry criteria) was 23.8 years and ranged from two days to 37 years. By comparison, the average interval since hire was 28.5 years (range $1.0-75 \cdot 1$ years), and the average duration of employment was 15.9 years (range 1.0-51.7 years). Men at the two refineries were nearly identical with respect to these variables.

Women contributed only 11722 years of observation because they were few $(n=677)$ and were hired more recently (average hire year for women $1965 v$ 1954 for men; results not shown). They experienced an average duration of employment and interval since hire of only 8.4 and 19.3 years respectively. Because they represented only $4.8 \%$ of all study participants and $1.9 \%$ of all observed deaths they were excluded from most analyses. Unless otherwise stated, the results presented pertain to men.

\section{CAUSE SPECIFIC MORTALITY AMONG MEN}

Table 3 shows the observed deaths, SMRs, and 95\% CIs for major causes of death. For both refineries combined, statistically significant deficits were found for all causes $(S M R=73)$, total cancer deaths $($ SMR $=81)$, and several individual cancer sitesnamely, buccal cavity and pharynx (SMR $=57)$, large intestine $(S M R=70)$, liver $(S M R=38)$, pancreas $(S M R=64)$, and lung $(S M R=75)$. With respect to causes of death other than cancer, statistically significant deficits were seen for most major organ systems, including diseases of the circulatory $(S M R=72)$, digestive $(S M R=69)$, and respiratory systems $(S M R=65)$.

Statistically significant increases over expected mortality were not identified for any single cause of death. Small non-significant increases were seen, however, for several causes including suicide (SMR $=120), \quad$ cancers of the oesophagus $(S M R=114), \quad$ larynx $\quad(S M R=120), \quad$ skin $(S M R=117)$, brain and central nervous system $(S M R=124)$, and other lymphatic tissues

Table 3 Observed deaths (obs), SMRs, and 95\% CIs for major causes among men at Richmond and El Segundo refineries

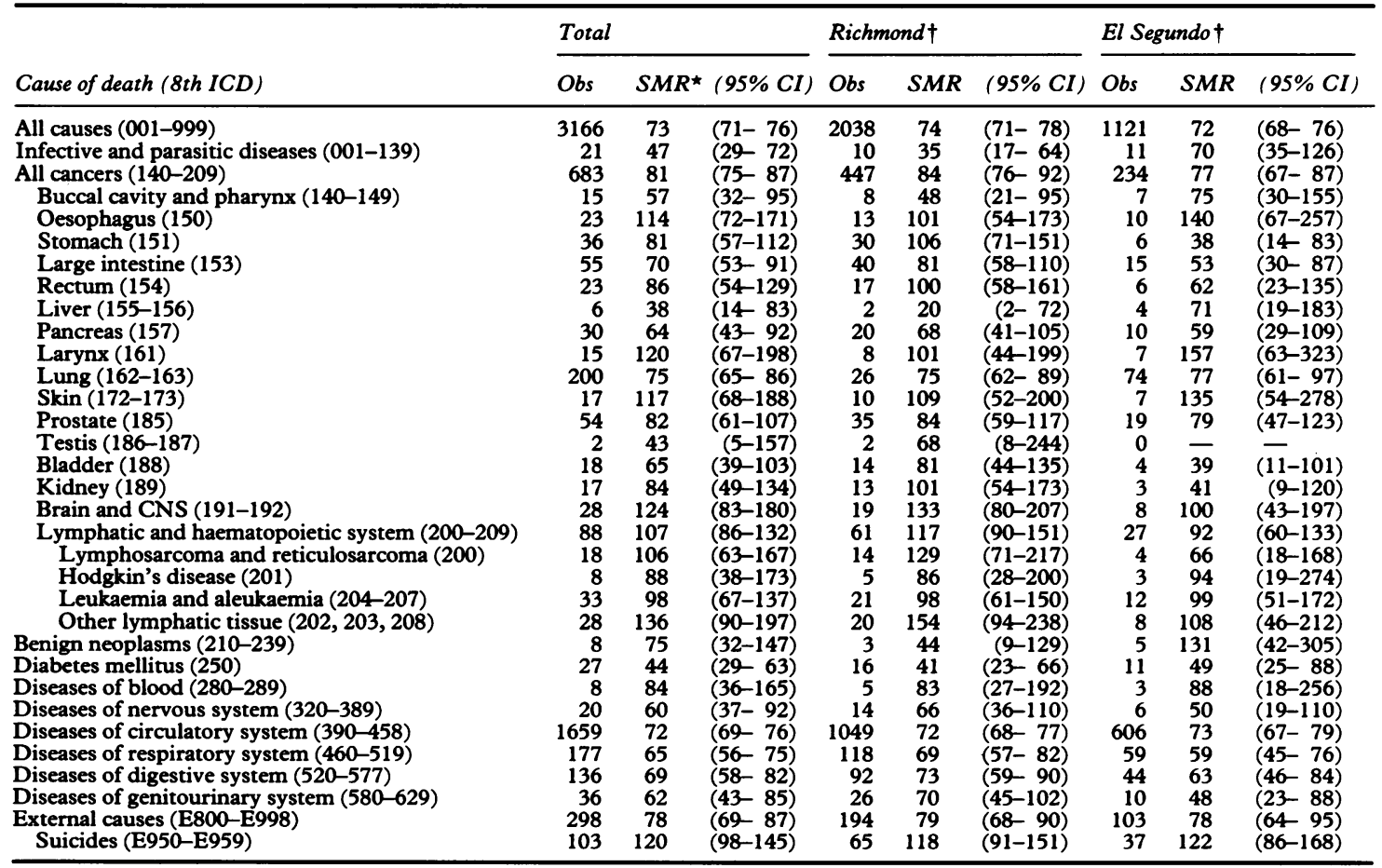

*Cause specific standardised mortality ratio (SMR; tables 3-8) = the ratio of observed over expected deaths $(\times 100)$ based on United States rates.

†Tables 3-8; cohort members who worked at both the Richmond and El Segundo refineries $(n=101)$ are excluded from refinery specific analyses. 
Table 4 Observed deaths (obs), SMRs, and 95\% CIs for selected cancers among men at Richmond refinery, ${ }^{\star}$ by duration of employment

\begin{tabular}{|c|c|c|c|c|c|c|c|c|c|c|c|c|}
\hline \multirow[b]{2}{*}{ Cancer site (8th ICD) } & \multicolumn{3}{|c|}{$<5$ years } & \multicolumn{3}{|c|}{$5-14$ years } & \multicolumn{3}{|c|}{ 15-29 years } & \multicolumn{3}{|c|}{$\geqslant 30$ years } \\
\hline & Obs & $S M R$ & $\dagger(95 \% C I)$ & Obs & $S M R$ & $(95 \% C I)$ & Obs & $S M R$ & $(95 \% C I)$ & Obs & $S M R$ & $(95 \% C I)$ \\
\hline \multirow{15}{*}{$\begin{array}{l}\text { All cancers (149-209) } \\
\text { Buccal cavity and } \\
\text { pharynx }(140-149) \\
\text { Oesophagus }(150) \\
\text { Stomach }(151) \\
\text { Large intestine (153) } \\
\text { Rectum }(154) \\
\text { Liver }(155-156) \\
\text { Pancreas }(157) \\
\text { Larynx }(161) \\
\text { Lung }(162-163) \\
\text { Skin }(172-173) \\
\text { Prostate }(185) \\
\text { Testis }(186-187) \\
\text { Bladder }(188) \\
\text { Kidney }(189) \\
\text { Brain and CNS } \\
\text { (191-192) } \\
\text { Lymphatic and }\end{array}$} & 46 & 97 & $(71-130)$ & 89 & 86 & $(69-106)$ & 136 & 76 & $(64-90)$ & 176 & 86 & $\left(\begin{array}{ll}74-99\end{array}\right)$ \\
\hline & 0 & - & $(0-259)$ & 2 & 60 & $(7-215)$ & 3 & 53 & $(11-154)$ & 3 & 50 & $(10-147)$ \\
\hline & 0 & - & $(0-384)$ & 4 & 161 & $(44-412)$ & 6 & 136 & $(50-296)$ & 3 & 62 & $(13-180)$ \\
\hline & 1 & 52 & $(1-290)$ & 2 & 36 & $(4-130)$ & 15 & 166 & $(93-273)$ & 12 & 102 & $(53-178)$ \\
\hline & 1 & 27 & $(1-153)$ & 7 & 79 & $(32-162)$ & 10 & 61 & $(29-112)$ & 22 & 108 & $(67-163)$ \\
\hline & 1 & 87 & $(2-482)$ & 5 & 158 & $(51-368)$ & 5 & 90 & $(29-210)$ & 6 & 85 & $(31-184)$ \\
\hline & $\begin{array}{l}0 \\
3\end{array}$ & $\overline{130}$ & $\begin{array}{r}(0-529) \\
(27-379)\end{array}$ & $\begin{array}{l}0 \\
3\end{array}$ & $\overline{55}$ & $\begin{array}{l}(0-190) \\
(11-159)\end{array}$ & 1 & $\begin{array}{l}31 \\
69\end{array}$ & $\begin{array}{l}(1-171) \\
(28-143)\end{array}$ & 1 & 24 & $(1-135)$ \\
\hline & $\begin{array}{l}3 \\
0\end{array}$ & 130 & $\begin{array}{r}(27-379) \\
(0-611)\end{array}$ & $\begin{array}{l}3 \\
1\end{array}$ & $\begin{array}{l}55 \\
66\end{array}$ & $\begin{array}{r}(11-159) \\
(2-367)\end{array}$ & $\begin{array}{l}7 \\
1\end{array}$ & $\begin{array}{l}69 \\
37\end{array}$ & $\begin{array}{r}(28-143) \\
(1-204)\end{array}$ & $\begin{array}{l}7 \\
6\end{array}$ & $\begin{array}{r}60 \\
200\end{array}$ & $\begin{array}{l}(24-124) \\
(73-435)\end{array}$ \\
\hline & 19 & 122 & $(73-190)$ & 38 & 118 & $(84-162)$ & 30 & 51 & $(34-72)$ & 39 & 63 & $(45-86)$ \\
\hline & 2 & 143 & $\begin{array}{r}(17-518) \\
(0-289)\end{array}$ & $\begin{array}{l}3 \\
2\end{array}$ & 132 & $(27-387)$ & 1 & 36 & $(1-198)$ & 4 & 148 & $(40-379)$ \\
\hline & $\begin{array}{l}0 \\
1\end{array}$ & $\overline{119}$ & $\begin{array}{l}(0-289) \\
(3-664)\end{array}$ & $\begin{array}{l}2 \\
0\end{array}$ & $\underline{34}$ & $\begin{array}{l}(4-124) \\
(0-370)\end{array}$ & $\begin{array}{r}14 \\
0\end{array}$ & 104 & $\begin{array}{r}(57-174) \\
(0-566)\end{array}$ & 19 & $\begin{array}{r}91 \\
210\end{array}$ & $\begin{array}{r}(55-142) \\
(5-1169)\end{array}$ \\
\hline & 1 & 117 & $(3-650)$ & 1 & 36 & $(1-202)$ & 5 & 87 & $(28-203)$ & 7 & 87 & $(35-179)$ \\
\hline & 3 & 239 & $(49-699)$ & 2 & 76 & $(9-276)$ & 2 & 46 & $(6-165)$ & 6 & 130 & $(48-283)$ \\
\hline & 2 & 88 & $(11-318)$ & 5 & 133 & $(43-310)$ & 6 & 128 & $(47-279)$ & 6 & 167 & $(61-363)$ \\
\hline & & & & & & & & & & & & \\
\hline $\begin{array}{l}(200-209) \\
\text { Lymphosarcoma and }\end{array}$ & 4 & 64 & $(17-163)$ & 9 & 79 & $(36-150)$ & 21 & 127 & $(79-194)$ & 27 & 152 & $(100-221)$ \\
\hline $\begin{array}{l}\text { reticulosarcoma } \\
(200)\end{array}$ & 0 & - & $(0-302)$ & 1 & 41 & $(1-227)$ & 5 & 140 & $(46-328)$ & 8 & 226 & $(97-445)$ \\
\hline $\begin{array}{l}\text { Hodgkin's disease } \\
(201) \\
\text { Leukaemia and }\end{array}$ & 1 & 80 & $(2-444)$ & 2 & 112 & $(14-405)$ & 2 & 125 & $(15-450)$ & 0 & - & $(0-307)$ \\
\hline $\begin{array}{l}\text { aleukaemia } \\
(204-207)\end{array}$ & 0 & - & $(0-161)$ & 2 & 44 & $(5-160)$ & 5 & 75 & $(24-176)$ & 14 & 180 & $(98-302)$ \\
\hline$(202,203,208)$ & 3 & 239 & $(49-699)$ & 4 & 160 & $(44-409)$ & 8 & 182 & $(79-360)$ & 5 & 103 & $(34-241)$ \\
\hline
\end{tabular}

$\star+$ See table 3 .

$(\mathrm{SMR}=136)$. The last category includes giant follicular lymphoma, lymphoma not elsewhere classified, multiple myeloma, and polycythaemia vera.

\section{Analysis of mortality by refinery location}

Mortality from all causes combined and most noncancer causes were similar at both refineries (see table 3). Differences were found for some non-malignant causes, however, and several site specific cancers. For example, a non-significant increase in benign neoplasms appeared only at El Segundo (SMR = $131 v$ 44 at Richmond). Also, SMRs for cancers of the skin $(S M R=135)$, oesophagus $(S M R=140)$ and larynx $(S M R=157)$ were increased at El Segundo, but were near expected values at Richmond (SMR $=109,101$, and 101 respectively). Conversely, increases in lymphoreticulosarcoma, cancer of the brain and central nervous system, and other lymphatic tissue cancer were either limited to or higher at Richmond.

The original study found few differences in SMRs between the refineries and therefore was focused on the total cohort. By contrast, the updated results suggest differing degrees of mortality risk across the refineries for several site specific cancers. As a result, a more in depth analysis of cancer mortality was performed for each refinery separately.
Analysis of cancer mortality by duration of employment and interval since hire

Tables 4 and 5 present the cancer mortality experience of Richmond refinery workers by duration of employment and interval since hire. Our analysis identified few remarkable patterns; however, a downward trend by employment duration was seen for lung cancer. By contrast, upward trends by duration of employment were found for brain and central nervous system cancer, lymphoreticulosarcoma, leukaemia, and the combined cancers of the lymphatic and haematopoietic tissue (the last being mainly lymphoreticulosarcoma and leukaemia). Also, among workers with at least 30 years of employment, the SMR for all lymphopoietic tissue cancers $(S M R=152)$ was statistically significant. A consistent pattern across duration of employment strata was not seen for other lymphatic tissue cancer.

Upward trends relative to interval since hire (table 5) were seen at Richmond for the combined category of lymphopoietic tissue cancers, and for the subcategory of leukaemia. A similar pattern was not found, however, for lymphoreticulosarcoma, brain and central nervous system cancer, or the other cancer sites evaluated. In fact, cancers of the brain and central nervous system and other lymphatic tissues were consistently raised across all strata by 
Table 5 Observed deaths (obs), SMRs, and 95\% CIs for selected cancers among men at Richmond refinery, ${ }^{\star}$ by interval since hire

\begin{tabular}{|c|c|c|c|c|c|c|c|c|c|c|c|c|}
\hline \multirow[b]{2}{*}{ Cancer site (8th ICD) } & \multicolumn{3}{|c|}{$<10$ years } & \multicolumn{3}{|c|}{$10-19$ years } & \multicolumn{3}{|c|}{ 20-29 years } & \multicolumn{3}{|c|}{$\geqslant 30$ years } \\
\hline & Obs & $S M R$ & $\dagger(95 \% \mathrm{CI})$ & Obs & $S M R$ & $(95 \%$ CI $)$ & Obs & $S M R$ & $(95 \% C I)$ & Obs & $S M R$ & $(95 \% C I)$ \\
\hline \multirow{16}{*}{$\begin{array}{c}\text { All cancers (140-209) } \\
\text { Buccal cavity and } \\
\text { pharynx (140-149) } \\
\text { Oesophagus (150) } \\
\text { Stomach (151) } \\
\text { Large intestine (153) } \\
\text { Rectum (154) } \\
\text { Liver (155-156) } \\
\text { Pancreas (157) } \\
\text { Larynx (161) } \\
\text { Lung (162-163) } \\
\text { Skin (172-173) } \\
\text { Prostate (185) } \\
\text { Testis (186-187) } \\
\text { Bladder (188) } \\
\text { Kidney (189) } \\
\text { Brain and CNS } \\
\text { (191-192) }\end{array}$} & 15 & 68 & $(38-112)$ & 41 & 69 & $(50-94)$ & 91 & 75 & $(60-92)$ & 300 & 90 & $(80-101)$ \\
\hline & 0 & - & $(0-553)$ & 0 & - & $(0-178)$ & 2 & 47 & $(6-168)$ & 6 & 63 & $(23-137)$ \\
\hline & 0 & - & $(0-823)$ & 1 & 69 & $(2-384)$ & 4 & 128 & $(35-327)$ & 8 & 102 & $(44-201)$ \\
\hline & 0 & - & $(0-291)$ & 2 & 57 & $(7-204)$ & 11 & 186 & $(93-333)$ & 17 & 97 & $(56-154)$ \\
\hline & 2 & 128 & $(16-462)$ & 0 & - & $(0-79)$ & 5 & 49 & $(16-114)$ & 33 & 100 & $(69-141)$ \\
\hline & 0 & - & $(0-567)$ & 2 & 105 & $(13-379)$ & 4 & 111 & $(30-285)$ & 11 & 102 & $(31-184)$ \\
\hline & 0 & 二 & $(0-780)$ & 0 & $\overline{61}$ & $(0-288)$ & 0 & $\overline{00}$ & $(0-177)$ & 2 & 32 & $(4-117)$ \\
\hline & $\begin{array}{l}\mathbf{0} \\
\mathbf{0}\end{array}$ & 二 & $\begin{array}{l}(0-403) \\
(0-1446)\end{array}$ & 2 & $\begin{array}{r}64 \\
114\end{array}$ & $\begin{array}{l}(8-229) \\
(3-634)\end{array}$ & 6 & $\begin{array}{l}89 \\
51\end{array}$ & $\begin{array}{r}(33-194) \\
(1-282)\end{array}$ & $\begin{array}{r}12 \\
6\end{array}$ & $\begin{array}{r}64 \\
125\end{array}$ & $\begin{array}{l}(33-112) \\
(46-272)\end{array}$ \\
\hline & 6 & $\overline{123}$ & $(45-267)$ & 14 & 81 & $(44-135)$ & 30 & 71 & $(48-101)$ & 76 & 73 & $(58-91)$ \\
\hline & 1 & 121 & $(3-676)$ & 1 & 60 & $(2-334)$ & 2 & 86 & $(10-311)$ & 6 & 138 & $(51-299)$ \\
\hline & 0 & - & $(0-986)$ & 0 & - & $(0-204)$ & 3 & 52 & $(11-152)$ & 32 & 95 & $(65-134)$ \\
\hline & 0 & - & $(0-419)$ & 1 & 123 & $(3-683)$ & 0 & - & $(0-709)$ & 1 & 134 & $(3-747)$ \\
\hline & 0 & - & $(0-1107)$ & 0 & - & $(0-297)$ & 2 & 65 & $(8-235)$ & 12 & 94 & $(49-165)$ \\
\hline & 0 & - & $(0-716)$ & 2 & 126 & $(15-456)$ & 0 & - & $(0-112)$ & 11 & 147 & $(73-263)$ \\
\hline & 2 & & $(17-491)$ & 4 & 139 & $(38-355)$ & 5 & 124 & $(40-289)$ & 8 & 135 & $(58-266)$ \\
\hline & \multicolumn{12}{|c|}{ Lymphatic and } \\
\hline $\begin{array}{l}\text { haematopoietic system } \\
(200-209)\end{array}$ & 1 & 23 & $(1-130)$ & 7 & 93 & $(37-191)$ & 11 & 96 & $(48-171)$ & 42 & 147 & $(106-198)$ \\
\hline reticulosarcoma & 0 & - & $(0-436)$ & 3 & 166 & $(34-485)$ & 2 & 74 & $(9-268)$ & 9 & 164 & $(75-312)$ \\
\hline $\begin{array}{l}\text { Hodgkin's disease } \\
\text { (201) }\end{array}$ & 0 & 一 & $(0-299)$ & 1 & 67 & $(2-374)$ & 3 & 233 & $(48-681)$ & 1 & 55 & $(1-304)$ \\
\hline $\begin{array}{l}\text { Leukaemia and } \\
\text { aleukaemia } \\
(204-207)\end{array}$ & 0 & - & $(0-215)$ & 1 & 34 & $(1-191)$ & 2 & 46 & $(6-165)$ & 18 & 146 & $(86-231)$ \\
\hline Other lymphatic tissue & & & & & & & & & & & & \\
\hline$(202,203,208)$ & 1 & 208 & $(5-1157)$ & 2 & 153 & $(19-551)$ & 4 & 134 & $(37-343)$ & 13 & 158 & $(84-271)$ \\
\hline
\end{tabular}

*†See table 3.

interval since hire. Several cancer sites showed increases primarily in the $>30$ year stratum, but only the combined category of all lymphopoietic cancers was statistically significant. The increase $(S M R=147)$ is attributable to non-significant increases in lymphoreticulosarcoma $(S M R=164)$, leukaemia (SMR = 146), and other lymphatic tissue cancer $($ SMR $=158)$.

At the El Segundo refinery, a downward gradient in lung cancer SMRs was found with increasing duration of employment (table 6). By contrast, a slight upward trend by duration of employment was seen for all lymphopoietic tissue cancers (combined); among workers with at least 30 years of employment, however, the observed number of deaths was close to that expected. With respect to interval since hire (table 7), all cases of other lymphatic tissue cancer occurred at least 30 years after initial hire.

\section{Analysis of cancer mortality by hire date}

The data for each refinery were stratified by year of hire into 1948 and earlier $v$ after 1948 . This was to evaluate potential differences in risks of cancer mortality associated with qualitatively estimated historical exposure to benzene, now recognised as a human carcinogen. A further discussion of the rationale with respect to benzene can be found in a previous publication. ${ }^{1}$ In a more general sense, our hire date analysis permitted an assessment of mortality patterns as they relate to older $v$ more contemporary work environments. In our study, men hired before $1949(n=5334)$ had a median of 40.6 years elapsed time between year of hire and end of follow up (range 2.0-75.1 years). Among men hired after 1948 , the median interval since hire was 19.9 years (range 1.0-38.0). This means that with the additional follow up, half of the workers hired after 1948 $(n=4031)$ had experienced a latency of between 20 and 38 years.

We found increases for Hodgkin's disease and cancers of the oesophagus, stomach, and kidney for men hired after 1948 (see table 8). All were based on a small number of observed deaths (five or less), however, and only the SMR for oesophageal cancer at El Segundo was statistically significant. For all other cancer sites, increases were either limited to, or more pronounced in men hired before 1949. For example, $11(92 \%)$ of the cases of laryngeal cancer occurred in the pre-1949 group, resulting in nonsignificant SMRs of 123 at Richmond and 168 at El Segundo. Similar patterns were seen for cancers of the brain and central nervous system and skin. The most striking difference by hire date was seen for cancers of the lymphopoietic tissues. Increases were 
Table 6 Observed deaths (obs), SMRs, and 95\% CIs for selected cancers among men at El Segundo refinery, ${ }^{\star}$ by duration of employment

\begin{tabular}{|c|c|c|c|c|c|c|c|c|c|c|c|c|}
\hline \multirow[b]{2}{*}{ Cancer site (8th ICD) } & \multicolumn{3}{|c|}{$<5$ years } & \multicolumn{3}{|c|}{ 5-14 years } & \multicolumn{3}{|c|}{ 15-29 years } & \multicolumn{3}{|c|}{$\geqslant 30$ years } \\
\hline & Obs & $S M R \dagger$ & $\dagger(95 \% C I)$ & Obs & $S M R$ & $(95 \% C I)$ & Obs & $S M R$ & $(95 \% C I)$ & Obs & SMR & $(95 \% C I)$ \\
\hline \multirow{2}{*}{$\begin{array}{l}\text { All cancers (140-209) } \\
\text { Buccal cavity and }\end{array}$} & 26 & 72 & $(47-105)$ & 44 & 83 & $(60-111)$ & 86 & 80 & $(64-99)$ & 78 & 73 & $(61-75)$ \\
\hline & 0 & - & $(0-309)$ & 0 & - & $(0-210)$ & 4 & 118 & $(32-302)$ & 3 & 100 & $(21-292)$ \\
\hline Oesophagus (150) & 1 & 117 & $(3-651)$ & 4 & 316 & $(86-810)$ & 4 & 156 & $(43-399)$ & 1 & 41 & $(1-227)$ \\
\hline Stomach (151) & 0 & - & $(0-243)$ & i & 37 & $(1-206)$ & 3 & 55 & $(11-161)$ & 2 & 33 & $(4-118)$ \\
\hline Large intestine (153) & 2 & 68 & $(8-246)$ & 1 & 22 & $(1-122)$ & 3 & 30 & $(6-88)$ & 9 & 83 & $(38-157)$ \\
\hline Rectum (154) & 0 & - & $(0-395)$ & 0 & - & $(0-229)$ & 4 & 118 & $(32-302)$ & 2 & 54 & $(7-194)$ \\
\hline Liver (155-156) & 0 & - & $(0-678)$ & 0 & - & $(0-382)$ & 2 & 102 & $(12-369)$ & 2 & 93 & $(11-337)$ \\
\hline Pancreas (157) & 0 & - & $(0-200)$ & 1 & 35 & $(1-195)$ & 5 & 83 & $(27-193)$ & 4 & 66 & $(18-168)$ \\
\hline Larynx (161) & 0 & - & $(0-713)$ & i & 127 & $(3-706)$ & 4 & 245 & $(67-627)$ & 2 & 131 & $(16-473)$ \\
\hline Lung (162-163) & 15 & 123 & $(69-203)$ & 18 & 105 & $(63-167)$ & 26 & 74 & $(48-108)$ & 15 & 48 & $(27-78)$ \\
\hline Skin $(172-173)$ & 1 & 104 & $(3-580)$ & 1 & 85 & $(2-471)$ & 2 & 121 & $(15-435)$ & 3 & 217 & $(45-634)$ \\
\hline Prostate (185) & 1 & 71 & $(2-396)$ & 3 & 108 & $(22-317)$ & 4 & 49 & $(13-124)$ & 11 & 94 & $(47-168)$ \\
\hline Testis $(186-187)$ & $\mathbf{0}$ & - & $(0-734)$ & 0 & - & $(0-734)$ & 0 & - & $(0-1044)$ & 0 & - & $(0-1524)$ \\
\hline Bladder (188) & 0 & - & $(0-474)$ & 0 & - & $(0-263)$ & 1 & 28 & $(1-156)$ & 3 & 68 & $(14-200)$ \\
\hline Kidney (189) & 0 & - & $(0-386)$ & 0 & - & $(0-267)$ & i & 38 & $(1-212)$ & 2 & 85 & $(10-306)$ \\
\hline Brain and CNS & & & & & & & & & & & & \\
\hline $\begin{array}{l}(191-192) \\
\text { Lymphatic and }\end{array}$ & 2 & 129 & $(16-466)$ & 1 & 50 & $(1-279)$ & 4 & 148 & $(40-379)$ & 1 & 57 & \\
\hline haematopoietic system & 2 & 46 & $(6-165)$ & 5 & 85 & $(27-197)$ & 10 & 102 & $(49-187)$ & 10 & 107 & $(51-196)$ \\
\hline $\begin{array}{l}\text { reticulosarcoma } \\
(200)\end{array}$ & 0 & - & $(0-412)$ & 2 & 157 & $(19-566)$ & 1 & 48 & $(1-267)$ & 1 & 55 & $(1-305)$ \\
\hline $\begin{array}{l}\text { Hodgkin's disease } \\
(201) \\
\text { Leukaemia and }\end{array}$ & 1 & 128 & $(3-715)$ & 1 & 110 & $(3-611)$ & 1 & 111 & $(3-621)$ & 0 & - & $(0-607)$ \\
\hline $\begin{array}{l}\text { Leukaemia and } \\
\text { aleukaemia } \\
\text { (204-207) }\end{array}$ & 0 & - & $(0-218)$ & 2 & 86 & $(11-312)$ & 5 & 125 & $(41-291)$ & 5 & 120 & $(39-280)$ \\
\hline $\begin{array}{l}\text { Other lymphatic tissue } \\
(202,203,208)\end{array}$ & 1 & 105 & $(3-584)$ & 0 & - & $(0-279)$ & 3 & 115 & $(24-335)$ & 4 & 160 & $(43-402)$ \\
\hline
\end{tabular}

$\star$ † See table 3.

mainly found among Richmond workers hired before 1949 , in whom a statistically significant increase $(S M R=137)$ was seen in the combined category. This increase was driven by a statistically significant increase in other lymphatic tissue cancer $(S M R=174)$ and a non-significant increase in lymphoreticulosarcoma $(S M R=166)$. By contrast, at the El Segundo refinery, mortality from leukaemia $(S M R=117)$ and other lymphatic tissue cancer $(S M R=121)$ was close to expected.

As most of the increases in the lymphopoietic cancers were limited to men hired before 1949, we again examined trends by duration of employment and interval since hire but limited the analysis to the pre-1949 hire group. In most cases, the results mirrored those seen in the overall refinery analyses discussed earlier. For other lymphatic tissue cancer, however, an inverse relation by duration of employment was seen at Richmond in the pre-1949 group. Among men with fewer than five years of employment, a statistically significant SMR of 839 occurred (based on three observed deaths) compared with non-significant SMRs of 247 (four observed deaths) and 191 (seven observed deaths) in the 5-14 and 15-29 year strata respectively. By contrast, a non-significant deficit (SMR $=85$, four observed deaths) was seen in the $>30$ year stratum.
CAUSE SPECIFIC MORTALITY AMONG WOMEN

Sixty two deaths occurred among the 677 women in the cohort, resulting in an SMR of $85(95 \%$ CI 65109) for all causes combined (not shown). Small numbers of deaths were found for most individual mortality causes, thus giving fairly unstable estimates. A statistically significant deficit, however, was seen for diseases of the circulatory system (SMR $=64,95 \%$ CI 40-96). Some causes of death showed non-significant increases, including cancer of the large intestine (SMR $=234,95 \%$ CI 76-546) and lung (SMR $=191,95 \%$ CI $52-490)$, but only oesophageal cancer $($ SMR $=1187,95 \%$ CI $=144$ 4286) and suicide (SMR $=416,95 \%$ CI 135-971) reached statistical significance. These SMRs were based on a total of two and five deaths respectively.

\section{ANALYSIS USING CALIFORNIA RATES}

The Richmond and El Segundo refineries are both located in California. It is a reasonable assumption that most cohort members resided in the state following termination or retirement. For some causes of death, California rates are substantially different from the corresponding United States rates. For these causes, California residents (as a whole) might 
Table 7 Observed deaths (obs), SMRs, and 95\% CIs for selected cancers among men at El Segundo refinery, ${ }^{\star}$ by interval since hire

\begin{tabular}{|c|c|c|c|c|c|c|c|c|c|c|c|c|}
\hline \multirow[b]{2}{*}{ Cancer site (8th ICD) } & \multicolumn{3}{|c|}{$<10$ years } & \multicolumn{3}{|c|}{$10-19$ years } & \multicolumn{3}{|c|}{ 20-29 years } & \multicolumn{3}{|c|}{$\geqslant 30$ years } \\
\hline & Obs & $S M R$ & $(95 \% C I)$ & Obs & $S M R$ & $(95 \% C I)$ & Obs & $S M R$ & $(95 \% C I)$ & Obs & $S M R$ & $(95 \% C I)$ \\
\hline \multirow{16}{*}{$\begin{array}{l}\text { All cancers (140-209) } \\
\text { Buccal cavity and } \\
\text { pharynx (140-149) } \\
\text { Oesophagus (150) } \\
\text { Stomach (151) } \\
\text { Large intestine (153) } \\
\text { Rectum (154) } \\
\text { Liver (155-156) } \\
\text { Pancreas (157) } \\
\text { Larynx (161) } \\
\text { Lung (162-163) } \\
\text { Skin (172-173) } \\
\text { Prostate (185) } \\
\text { Testis (186-187) } \\
\text { Bladder (188) } \\
\text { Kidney (189) } \\
\text { Brain and CNS } \\
\text { (191-192) }\end{array}$} & 4 & 30 & $8-77$ & 26 & 77 & $(50-113)$ & 46 & 67 & $(49-\quad 89)$ & 158 & 84 & $(71-98)$ \\
\hline & 0 & - & $(0-926)$ & 0 & - & $(0-309)$ & 0 & - & $(0-148)$ & 7 & 133 & $(54-274)$ \\
\hline & 1 & 391 & $(10-2178)$ & 1 & 125 & $(3-698)$ & 3 & 170 & $(35-496)$ & 5 & 116 & $(38-270)$ \\
\hline & 0 & - & $(0-517)$ & 0 & - & $(0-198)$ & 2 & 60 & $(7-215)$ & 4 & 41 & $(11-104)$ \\
\hline & 0 & - & $(0-386)$ & 1 & 38 & $(1-210)$ & 3 & 51 & $(11-150)$ & 11 & 58 & $(29-104)$ \\
\hline & 0 & - & $(0-970)$ & 3 & 284 & $(59-829)$ & 0 & - & $(0-177)$ & 3 & 49 & $(10-143)$ \\
\hline & 0 & - & $(0-1394)$ & 0 & - & $(0-547)$ & 0 & - & $(0-306)$ & 4 & 115 & $(32-296)$ \\
\hline & 0 & - & $(0-662)$ & 0 & - & $(0-206)$ & 3 & 78 & $(16-228)$ & 7 & 66 & $(26-136)$ \\
\hline & 0 & - & $(0-2463)$ & 1 & 199 & $(5-1107)$ & 0 & - & $(0-321)$ & 6 & 225 & $(83-490)$ \\
\hline & 2 & 65 & $(8-236)$ & 11 & 107 & $(53-191)$ & 15 & 62 & $(34-101)$ & 46 & 79 & $(58-105)$ \\
\hline & 0 & - & $(0-710)$ & 1 & 106 & $(3-588)$ & 2 & 155 & $(19-560)$ & 4 & 165 & $(45-421)$ \\
\hline & 0 & - & $(0-1622)$ & 0 & - & $(0-398)$ & 2 & 66 & $(8-238)$ & 17 & 85 & $(50-136)$ \\
\hline & 0 & - & $(0-729)$ & 0 & - & $(0-888)$ & 0 & - & $(0-1368)$ & 0 & - & $(0-901)$ \\
\hline & 0 & - & $(0-1880)$ & 0 & - & $(0-534)$ & 0 & - & $(0-208)$ & 4 & 53 & $(15-137)$ \\
\hline & 0 & - & $(0-1175)$ & 1 & 108 & $(3-601)$ & 0 & - & $(0-195)$ & 2 & 48 & $(6-173)$ \\
\hline & 0 & - & $(0-415)$ & 2 & 121 & $(15-438)$ & 3 & 132 & $(27-385)$ & 3 & 94 & $(20-276)$ \\
\hline Lymphatic and & & & & & & & & & & & & \\
\hline $\begin{array}{l}\text { haematopoietic system } \\
(200-209) \\
\text { Lymphosarcoma and }\end{array}$ & 0 & - & $(0-147)$ & 4 & 95 & $(26-244)$ & 4 & 62 & $(17-159)$ & 19 & 116 & $(70-181)$ \\
\hline $\begin{array}{l}\text { reticulosarcoma } \\
(200)\end{array}$ & 0 & - & $(0-745)$ & 2 & 198 & $(24-714)$ & 0 & - & $(0-243)$ & 2 & 65 & $(8-236)$ \\
\hline $\begin{array}{l}\text { Hodgkin's disease } \\
(201) \\
\text { Leukaemia and }\end{array}$ & 0 & - & $(0-524)$ & 0 & - & $(0-467)$ & 2 & 285 & $(34-1028)$ & 1 & 100 & $(3-558)$ \\
\hline aleukaemia & 0 & - & $(0-371)$ & 2 & 125 & $(15-451)$ & 2 & 82 & $(10-295)$ & 8 & 112 & $(48-221)$ \\
\hline $\begin{array}{l}\text { Other lymphatic tissue } \\
(202,203,208)\end{array}$ & $e_{0}$ & - & $(0-1229)$ & 0 & - & $(0-478)$ & 0 & - & $(0-219)$ & 8 & 171 & $(74-337)$ \\
\hline
\end{tabular}

* + See table 3.

be a more appropriate reference population for our cohort analysis.

We were able to obtain California death rates for two periods (1950-86 for malignancies and 1962-86 for non-cancers). Our comparison with United States rates found substantial differences for four causes of death-namely, suicide, laryngeal cancer, Hodgkin's disease, and malignant melanoma. For example, suicide rates among men in California were on average $28 \%$ higher than United States rates. The rates among women were an average of $72 \%$ higher. Death rates for laryngeal cancer and Hodgkin's disease were some $10 \%$ lower among California men, whereas malignant melanoma rates were an average of $17 \%$ higher. Differences for these three causes of death were less pronounced among women. As a result of these regional differences, we evaluated mortality in our cohort from these four causes of death, based on a comparison with California rates. Relative to statewide patterns, male cohort members at Richmond and El Segundo had fewer suicide deaths than expected (SMR $=94$ and 97 respectively). Also, the increase for women fell from 416 (based on a comparison with United States rates) to 265 , and was no longer statistically significant. Using California as the reference population, we found non-significant laryngeal cancer SMRs of 121 and 187 for men at the Richmond and El Segundo refineries respectively. The corresponding SMRs for Hodgkin's disease were 105 and 116, and were nonsignificant. Mortality from malignant melanoma was also non-significantly raised in men relative to statewide values (SMR = 110 for Richmond and 130 for El Segundo). Our earlier analysis of skin cancer was based on the combined category of malignant melanoma and other malignant neoplasms of the skin; SMRs for malignant melanoma alone, based on a comparison with United States men, were 126 for Richmond and 149 for El Segundo.

\section{Discussion}

As with the previous study, this update showed that overall, men at the Richmond and El Segundo refineries experienced substantially lower death rates than expected based on a comparison with the corresponding United States general population. Large, and in many cases, statistically significant deficits were found in all major cause of death categories at both refineries. The favourable mortality experience of our cohort is consistent with the results of other published studies of petroleum 
Table 8 Observed deaths (obs), SMRs, and 95\% CIs for selected cancers among men at Richmond and El Segundo refineries, stratified by hire date

\begin{tabular}{|c|c|c|c|c|c|c|c|c|c|c|c|c|}
\hline \multirow[b]{3}{*}{ Cancer site (8th ICD) } & \multicolumn{6}{|c|}{ Richmond refinery* } & \multicolumn{6}{|c|}{ El Segundo refinery* } \\
\hline & \multicolumn{3}{|c|}{1948 or before } & \multicolumn{3}{|c|}{ After 1948} & \multicolumn{3}{|c|}{1948 or before } & \multicolumn{3}{|c|}{ After 1948} \\
\hline & Obs & $S M R$ & $(95 \%$ CI $)$ & Obs & $S M R$ & $(95 \% C I)$ & Obs & $S M R$ & $(95 \% C I)$ & Obs & $S M R$ & $(95 \% C I)$ \\
\hline \multirow{17}{*}{$\begin{array}{l}\text { All cancers }(140-209) \\
\text { Buccal cavity and } \\
\text { pharynx }(140-149) \\
\text { Oesophagus }(150) \\
\text { Stomach }(151) \\
\text { Large intestine (153) } \\
\text { Rectum (154) } \\
\text { Liver }(155-156) \\
\text { Pancreas }(157) \\
\text { Larynx }(161) \\
\text { Lung }(162-163) \\
\text { Skin }(172-173) \\
\text { Prostate }(185) \\
\text { Testis }(186-187) \\
\text { Bladder }(188) \\
\text { Kidney (189) } \\
\text { Brain and CNS } \\
\text { (191-192) } \\
\text { Lymphatic and } \\
\text { haematopoietic system } \\
\text { (200-209) } \\
\text { Lymphosarcoma and } \\
\text { reticulosarcoma } \\
\text { (200) } \\
\text { Hodgkin's disease }\end{array}$} & 374 & 85 & $(77-94)$ & 73 & 75 & $(59-95)$ & 186 & 77 & $(66-88)$ & 48 & 78 & $(58-104)$ \\
\hline & 8 & 60 & $(26-118)$ & 0 & - & - & 6 & 83 & $(30-180)$ & 1 & 48 & $(1-270)$ \\
\hline & 10 & 95 & $(46-176)$ & 3 & 125 & $(26-365)$ & 5 & 89 & $(29-207)$ & 5 & 334 & $(108-779)$ \\
\hline & 25 & 102 & $(66-151)$ & 5 & 131 & $(43-306)$ & 6 & 45 & $(17-98)$ & 0 & - & \\
\hline & 37 & 88 & $(62-122)$ & 3 & 40 & $(8-116)$ & 12 & 51 & $(26-89)$ & 3 & 61 & $(13-179)$ \\
\hline & 17 & 116 & $\begin{array}{r}(68-186) \\
(3-84)\end{array}$ & 0 & $\underline{-}$ & - & 4 & 49 & $(13-126)$ & 2 & 132 & $(16-478)$ \\
\hline & $\begin{array}{r}2 \\
17\end{array}$ & $\begin{array}{l}23 \\
69\end{array}$ & $(40-110)$ & 3 & $\overline{62}$ & $(13-\overline{181})$ & $\begin{array}{l}4 \\
9\end{array}$ & $\begin{array}{l}84 \\
66\end{array}$ & $\begin{array}{l}(23-210) \\
(30-125)\end{array}$ & $\begin{array}{l}0 \\
1\end{array}$ & $\overline{32}$ & $(1-\overline{179})$ \\
\hline & 8 & 123 & (53-242) & 0 & - & - & 6 & 168 & $(62-365)$ & i & 113 & $(3-628)$ \\
\hline & 97 & 72 & $(58-88)$ & 29 & 87 & $(58-124)$ & 54 & 72 & $(54-94)$ & 20 & 94 & $(57-145)$ \\
\hline & 7 & 109 & $(44-225)$ & 3 & 108 & $(22-316)$ & & 143 & $(46-334)$ & 2 & 118 & $(14-427)$ \\
\hline & $\begin{array}{r}35 \\
1\end{array}$ & $\begin{array}{l}90 \\
62\end{array}$ & $\begin{array}{r}(63-125) \\
(2-348)\end{array}$ & $\begin{array}{l}0 \\
1\end{array}$ & $\overline{73}$ & $(2-\overline{409})$ & $\begin{array}{r}17 \\
0\end{array}$ & 77 & $(45-123)$ & $\begin{array}{l}2 \\
0\end{array}$ & $\underline{97}$ & $(12-350)$ \\
\hline & 13 & 83 & $(44-142)$ & 1 & 57 & $(1-315)$ & 4 & $\overline{45}$ & $(12-115)$ & 0 & - & - \\
\hline & 9 & 88 & $(40-167)$ & 4 & 152 & $(41-389)$ & 3 & 53 & $(11-155)$ & 0 & - & - \\
\hline & 14 & 141 & $(77-237)$ & 5 & 113 & $(37-264)$ & 7 & 131 & $(53-271)$ & 1 & 37 & $(1-209)$ \\
\hline & & & & & & & & & & & & \\
\hline & 55 & 137 & $(103-178)$ & 6 & 51 & $(19-110)$ & 22 & 99 & $(62-150)$ & 5 & 69 & $(22-161)$ \\
\hline & 14 & 166 & $(91-279)$ & $\mathbf{0}$ & - & - & 3 & 65 & $(13-190)$ & 1 & 68 & $(2-376)$ \\
\hline $\begin{array}{l}\text { Hodgkin's disease } \\
(201) \\
\text { Leukaemia and }\end{array}$ & 2 & 54 & $(7-194)$ & 3 & 142 & $(29-414)$ & 1 & 51 & $(1-282)$ & 2 & 164 & $(20-593)$ \\
\hline $\begin{array}{l}\text { aleukaemia } \\
(204-207)\end{array}$ & 20 & 119 & $(73-183)$ & 1 & 22 & $(1-124)$ & 11 & 117 & $(58-209)$ & 1 & 36 & $(1-202)$ \\
\hline $\begin{array}{c}\text { Other lymphatic tiss } \\
(202,203,208)\end{array}$ & 18 & 174 & $(103-275)$ & 2 & 76 & $(9-274)$ & 7 & 121 & $(49-250)$ & 1 & 60 & $(2-335)$ \\
\hline
\end{tabular}

$\star$ S See table 3.

workers. ${ }^{5-16}$ It suggests a strong healthy worker effect, which is the result of several factors. Firstly, people with serious illnesses are less likely to enter into the workforce. Secondly, employees of a large corporation, such as Chevron, are more likely to receive better medical benefits and health care, which we would expect to have a favourable impact on mortality patterns relative to the general public. Thirdly, the employed sector of society usually enjoys a more stable and healthy lifestyle, resulting in lower mortalities for many causes of death.

Despite the overall favourable results, we found increased SMRs for several cause specific outcomes, some of which are consistent with previous studies in the industry. The largest was found for other lymphatic tissue cancer, a heterogeneous group of malignancies including giant follicular lymphoma, lymphoma not elsewhere classified, multiple myeloma, and polycythaemia vera. Similar increases have been reported in other studies of refinery workers. ${ }^{6-8101116}$ Further analysis in this update by individual refinery and hire date showed that the excess in other lymphatic tissue cancer was confined to employees hired before 1949 , principally at the Richmond refinery $(S M R=174, p<0.05)$. No indication existed for any increased risk in employees hired after this date. This pattern could reflect an occupational exposure that decreased after 1948, a non-casual association found in the pre-1949 period, or insufficient follow up. We think that insufficient follow up is an unlikely explanation as half of the male cohort members hired after 1948 had experienced a latency of between 20 and 38 years. A causal explanation is also unlikely given the lack of an upward trend by interval since hire and the existence of an inverse relation by duration of employment (at Richmond).

By contrast with other lymphatic tissue cancer, our analyses by hire date and duration of employment suggest that the increases in leukaemia and lymphoreticulosarcoma might be related to historical occupational exposures. For these causes of death, we found increases in workers hired before 1949, and in the case of lymphoreticulosarcoma, these were seen only at the Richmond refinery. Also, mortality from leukaemia and lymphoreticulosarcoma increased with increasing duration of employment. If we treat duration of employment as a surrogate for duration of exposure in the workplace, these upward trends suggest dose-response relations.

Our findings for leukaemia are consistent with 
raised SMRs reported in other refinery worker studies. ${ }^{61015-18}$ For example, Morgan and Wong ${ }^{7}$ identified a statistically significant $73 \%$ excess in leukaemia, as well as an increase in risk with increasing duration of service among white men. Similarly, in an unpublished update ${ }^{18}$ to their original refinery study, ${ }^{6}$ Wen et al found a significant leukaemia excess (SMR $=163$ ) among employees working 20 or more years, along with an upward trend by duration of employment. Of these leukaemia deaths, $84 \%$ occurred among workers hired before 1945 . Wongsrichanalai et al ${ }^{15}$ also confirmed an excess risk of a leukaemia (SMR = 167, p < 0.05) among men with at least 10 years of employment (compared with a non-significant SMR of 112 among men employed fewer than 10 years). Whereas a study by Marsh $e t$ $a l^{16}$ did not find an overall leukaemia mortality excess, a non-significant upward gradient in leukaemia SMRs was seen relative to duration of refinery employment. Finally, a recent analysis ${ }^{17}$ of over 20 petroleum industry studies concluded that certain subgroups of employees, particularly those hired before the 1940s, may be at increased risk of leukaemia.

By comparison, few reports exist of increases in lymphoreticulosarcoma among refinery populations, ${ }^{7916}$ and only one ${ }^{16}$ showed a statistically significant upward trend by duration of employment. This study, by Marsh $e t$ al, found a statistically significant SMR of 816 among men with at least 30 years of employment (compared with SMRs of 92 and 69 in men with under 20 and 20-29 years of refinery employment respectively). Although these results suggest that increases in lymphoreticulosarcoma might be occupationally related, we recognise that the inconsistency in our results between refineries for lymphoreticulosarcoma weakens the argument for an occupational aetiology (presuming the overall exposures were similar at the two refineries). Unfortunately, the absence of detailed historical exposure data precludes us from directly comparing the two refineries and therefore a causal interpretation of these data must remain speculative.

With respect to other cancer sites, we found increases in laryngeal cancer among workers hired before 1949. The same pattern was not seen for oesophageal cancer, for which a statistically significant increase occurred only among those hired at El Segundo after 1948. A study of eight oil refineries in the United Kingdom also showed an increase in oesophageal cancer (among operators). ${ }^{5}$

Publications have, however, typically reported deficits or SMRs close to expected values for both of these cancers. ${ }^{679111516}$ Also, as information is lacking for our cohort regarding known risk factors (for example, smoking, alcohol consumption), assessment of potential confounding is precluded.

Within the petroleum industry, some attention has also been focused on cancers of the brain, kidney, and lung. ${ }^{17} 19$ In the present study, only brain cancer exhibited a pattern of increased risk, mainly among employees hired before 1949. An upward trend in brain and central nervous system cancer was found at the Richmond refinery; however SMRs were consistently higher across all interval since hire strata. This pattern is not suggestive of an occupationally related disease. An alternate explanation for the slight increase in brain and central nervous system cancer may come from what Greenwald $e t a l^{20}$ refer to as diagnostic sensitivity bias. Among working populations who are medically well insured, there may be improved diagnosis and death certification of brain cancer (for example, through more frequent pathological confirmations of diagnoses). As Wong et al ${ }^{1}$ pointed out in the original study, differential diagnostic practices could result in an apparent mortality increase relative to the general population (in which brain tumours may be undiagnosed or misdiagnosed).

We found a non-significant increase in kidney cancer among Richmond employees hired after 1948. It was based on only four observed deaths, however, and must therefore be interpreted with caution. By contrast, SMRs for cancers of the liver and lung were at or below expected values in the individual refinery analyses. In fact, at both the Richmond and $\mathrm{El}$ Segundo refineries, we found statistically significant deficits for lung cancer, the second actually being inversely proportional to duration of employment.

With respect to our choice of a reference population, we think that the use of United States mortality rates did not introduce any substantial geographical bias for most causes examined. An examination of United States and California death rates, however, identified regional differences for four causes (laryngeal cancer, Hodgkin's disease, malignant melanoma, and suicide), which we thought were important to take into consideration. For example, our analysis found mortality from suicide to be increased relative to the general United States population. When we compared cohort mortality patterns with the experience of California residents, however, we found that men at Richmond and El Segundo had fewer suicides than expected. Similarly, the nonsignificant increases in malignant melanoma were partially explained by regional differences in mortality (malignant melanoma being higher, on average, among California residents than in the United States as a whole). By contrast, our use of United States rates may have resulted in a small underestimation of mortality risk for laryngeal cancer experienced by cohort members.

With the relatively few women in the cohorts, very little can be determined about their mortality experience. With respect to the statistically significant rise in oesophageal cancer, it does not appear 
to be occupationally related as a review of their employment records showed that the two cases held non-exposed office positions.

Limitations are inherent in any historical cohort study of this type, including the lack of documentation regarding known risk factors (for example, smoking), past workplace exposures, and other potential confounding variables. Hence our ability to assess their influence on the results is limited and the SMRs found in this study need to be interpreted with caution. Recognising these limitations, this six year update indicates that, in general, employees at the Richmond and El Segundo refineries have not experienced any unfavourable mortality risks compared with the general United States population. It is unclear whether the excess mortality for leukaemia and lymphoreticulosarcoma was occupationally related. If it was, the excess appears to be confined to a subgroup of workers hired before 1949. Most causes examined continue to show lower rates, even with a high percentage of cohort members who are long term employees and who have been followed up for several decades.

1 Wong O, Morgan RW, Bailey WJ, Swencicki RE, Claxton K, Kheifets L. An epidemiological study of petroleum refinery employees. Br J Ind Med 1986;43:6-17.

2 World Health Organisation. Manual of the international statistical classification of diseases, injuries and causes of death, based on the recommendations of the eighth revision conference, 1965, and adopted by the nineteenth World Health Assembly. Vols I and II. Geneva: WHO, 1967, 1968.

3 Marsh GM, Preninger M. OCMAP: a user-oriented occupational cohort mortality analysis program. Am Stat 1980;34:254.
4 Bailar JC, Ederer F. Significance factors for the ratio of a Poisson variable to its expectation. Biometrics 1954;20:639-42.

5 Rushton L, Alderson MR. An epidemiological survey of eight oil refineries in Britain. Br J Ind Med 1981;38:225-34.

6 Wen CP, Tsai SP, McClellan WA, Gibson RL. Long-term mortality study of oil refinery workers. I. Mortality of hourly and salaried workers. Am J Epidemiol 1983;118:526-42.

7 Morgan RW, Wong O. An epidemiologic analysis of the mortality experience of Mobil Oil Corporation employees at the Beaumont, Texas, refinery. Technical report submitted to Mobil Oil Corporation, 1984

8 McCraw DS, Joyner RE, Cole P. Excess leukaemia in a refinery population. J Occup Med 1985;27:220-2.

9 Hanis NM, Shallenberger LG, Donaleski DL, Sales EA. A retrospective mortality study of workers in three major U.S. refineries and chemical plants. Part 1: Comparisons with U.S population. J Occup Med 1985;27:283-92.

10 Divine BJ, Barron V, Kaplan SD. Texaco mortality study: I. Mortality among refinery, petrochemical and research workers. J Occup Med 1985;27:445-7.

11 Kaplan SD. Update of a mortality study of workers in petroleum refineries. J Occup Med 1986;28:514-6.

12 Theriault G, Provencher S. Mortality study of oil refinery workers: five-year follow-up. J Occup Med 1987;29:357-60.

13 Nelson NA, Van Peenen PFD, Blanchard AG. Mortality in a recent oil refinery cohort. J Occup Med 1987;29:610-2.

14 Divine BJ, Barron V. Texaco mortality study. III. A cohort study of producing and pipeline workers. Am J Ind Med 1987;11:189-202.

15 Wongsrichanalai C, Delzell E, Cole P. Mortality from leukemia and other diseases among workers at a petroleum refinery. $J$ Occup Med 1989;31:106-11.

16 Marsh GM, Enterline PE, McCraw D. Mortality patterns among refinery and chemical plant workers. Am J Ind Med 1991;19:29-42.

17 Wong O, Raabe GK. Critical review of cancer epidemiology in petroleum industry employees, with a quantitative metaanalysis by cancer site. Am J Ind Med 1989;15:283-310.

18 Wen CP, Tsai SP, Moffit K, Bondy M, Runion H, Gibson RL. Leukemia among oil refinery workers and residents in the surrounding communities. (With additional updated tables for leukemia). Presented at the Seminar on Cancer Prevention and Control in Texas in San Antonio, Texas, February, 1984 (sponsored by the Texas Department of Health.)

19 Savitz DA, Moure R. Cancer risk among oil refinery workers. A review of epidemiologic studies. JOccup Med 1984;26:662-70.

20 Greenwald P, Friedlander BR, Lawrence CE, Hearn T, Earle K. Diagnostic sensitivity bias-an epidemiologic explanation for an apparent brain tumor excess. J Occup Med 1981;23:690-4.

Accepted 15 July 1991 